Article

\title{
Prevalence of Antibiotic Resistance Genes in Pharmaceutical Wastewaters
}

\author{
Amarachukwu Obayiuwana ${ }^{1, *}$, Adeniyi Ogunjobi ${ }^{2}$ and Abasiofiok Ibekwe ${ }^{3}$ (D) \\ 1 Department of Biological Sciences, Augustine University Ilara-Epe, Epe 106101, Lagos State, Nigeria \\ 2 Department of Microbiology, University of Ibadan, Ibadan 200284, Oyo State, Nigeria; \\ aa.ogunjobi@mail.ui.edu.ng \\ 3 U.S. Salinity Laboratory, USDA-ARS, 450 West Big Springs Road, Riverside, CA 92507, USA; \\ mark.ibekwe@ARS.USDA.GOV \\ * Correspondence: amarachukwu.obayiuwana@augustineuniversity.edu.ng; Tel.: +234-803-789-2528
}

Citation: Obayiuwana, A.; Ogunjobi,

A.; Ibekwe, A. Prevalence of

Antibiotic Resistance Genes in

Pharmaceutical Wastewaters. Water

2021, 13, 1731. https://doi.org/

10.3390/w13131731

Academic Editors:

Helvi Heinonen-Tanski and

Luiza Campos

Received: 30 April 2021

Accepted: 20 June 2021

Published: 23 June 2021

Publisher's Note: MDPI stays neutral with regard to jurisdictional claims in published maps and institutional affiliations.

Copyright: (C) 2021 by the authors Licensee MDPI, Basel, Switzerland. This article is an open access article distributed under the terms and conditions of the Creative Commons Attribution (CC BY) license (https:/ / creativecommons.org/licenses/by/ $4.0 /)$.

\begin{abstract}
Pharmaceutical wastewaters are recognized as reservoirs of antibiotic resistance genes (ARGs) and antibiotic resistant bacteria (ARB), and also as hotspots for their horizontal gene transfer (HGT) using mobile genetic elements. Our study employed the use of PCR analysis of metagenomic DNA samples obtained from four pharmaceutical wastewaters using known primers to study the prevalence of thirty-six ARGs and four MGEs active against the commonly used antibiotics in Nigeria. The ARGs most frequently detected from the metagenomic DNA samples in each of the antibiotic classes under study include tetracycline [tet $(\mathrm{G})]$, aminoglycoside [aadA, strA and strB], chloramphenicol [catA1], sulphonamides [sulI and sulII], and $\beta$-lactams and penicillins [bla $\left.{ }_{\mathrm{OXA}}\right]$. The ARGs showed a $100 \%$ prevalence in their various environmental sources. The pharmaceutical facility PFIV showed the highest concentration of ARGs in this study. The highest concentration for MGEs was shown by pharmaceutical facility PFIII, positive for intl1, intl2, and IFS genes. This study highlights the wide distribution of ARGs to the antibiotics tested in the wastewater, making pharmaceutical wastewater reservoirs of ARGs which could potentially be transferred from commensal microorganisms to human pathogens.
\end{abstract}

Keywords: metagenomics; pharmaceutical wastewater; metagenomic DNA; Antibiotic-resistance genes (ARGs); mobile genetic elements (MGEs)

\section{Introduction}

Resistance to antibiotics in clinical therapy in both humans and animals is receiving considerable attention in public health worldwide [1,2]. Pharmaceutical wastewater environments play an important role in the dissemination of antibiotic resistance determinants. They have been reported as reservoirs for antibiotic-resistant bacteria (ARB) and antibiotic resistance genes (ARGs) [3,4], such as bla $a_{\mathrm{TEM}}$, ermF, mecA, tetA, etc. [5]; and hotspots for horizontal gene transfer (HGT), enabling the transfer of antibiotic resistance genes between different bacterial species [6]. This can be promoted by the presence of chemicals of emerging concern (CECs), such as antibiotics. Antibiotics such as trimethoprim, amoxicillin, sulfadiazine, etc. have been found in both influent and effluent of a wastewater treatment plant in varying amounts [7]. Even in low concentrations in wastewater, CECs can insert selective pressure for antibiotic resistance, contributing to the evolution and spread of ARGs [2]. The presence of high-density ARB in pharmaceutical wastewater environments, as demonstrated in previous studies [3,8], are likely to facilitate an enabling environment for HGT among environmental bacteria and human pathogens [9]. The location of ARGs on mobile genetic elements (MGEs), such as plasmids, transposons, and integrons, make the transfer of resistance determinants possible and easy to achieve among bacteria from the same or different origins [10]. 
Although the growing threat of antibiotic resistance to public health is recognized worldwide, the diversity, distribution, and fate of ARGs in wastewater systems remains unclear [11]. Many studies have employed various approaches to explain these grey areas of concern. Most of these studies on antibiotic resistance have focused on clinically relevant pathogens [12,13], isolating pure cultures [3], extracting genomic DNA, and applying amplification-based methods to investigate the occurrence and abundance of various ARGs in environmental samples $[3,4,14,15]$. Although this method has been, and still is, the most important method in clinical microbiology, there are limitations in applying it to the study of environmental bacteria [16]. The major limitation is the growth of only a fraction of environmental bacteria under laboratory conditions. However, with the combination of molecular biology tools, such as the polymerase chain reaction technology, insightful information on the widespread occurrence and abundance of ARGs can be more effectively studied. The PCR detection depends on available primers that are based on known resistance gene and is not suitable for the discovery of novel ARGs [17]. To overcome this drawback of the PCR-based methods, metagenomic sequencing is employed $[17,18]$ and can be used for broad-spectrum screening of ARGs.

Metagenomics is a varietal tool that employs the sequencing of the whole community DNA that have been applied in diverse environments to study antibiotic resistance determinants and to describe the mechanisms of resistance and their evolution in bacterial communities within the ecosystem [6]. These studies do not necessarily require prior knowledge of the chosen gene, however, the most reliable annotations of ARGs are those gotten from known genes in public antibiotic-resistance gene databases [19-21]. Metagenomic tools have been employed extensively in studying environmental ARGs and have demonstrated such compartments as hotspots for ARGs and MGEs [22]. This tool was employed in a large-scale study of antibiotic resistance in nonclinical environments, describing the diverse, abundant, and non-random distribution of ARGs in them [23]. Additionally, in a similar study, metagenomic and network analysis reveals the distribution and cooccurrence of environmental ARGs [24]. In another study, metagenomic tools were applied in antibiotic resistance studies in diverse wastewater treatment plants at various stages. The variation of antibiotic resistance genes in activated sludge of a WWTP was explored over four years through a metagenomic approach [25]. A study [13] in a WWTP in China applied a whole genome sequencing of extended-spectrum of beta-lactamase (ESBL)-producing Escherichia coli isolated from the plant, revealing resistant strains of E. coli.

This study is aimed at evaluating pharmaceutical wastewater as reservoirs of ARGs and MGEs which could potentially be transferred to human pathogens. This study investigated the occurrence of ARGs and MGEs profiles in metagenomic DNA samples obtained from wastewaters of four pharmaceutical facilities in Sango-Ota, Ogun State, Nigeria over a period of six months, using the amplification-based method. Our previous studies [3,4] on these plants were based on the evaluation of genomic DNA from bacterial isolates for the same ARGs. The selected pharmaceutical facilities play important roles in antibiotic production in the region. Varying classes of antibiotics and other drug types are produced on a single production plant in these facilities. There were no wastewater treatment plants on-site in any of the four facilities.

\section{Materials and Methods}

\subsection{Study Sites and Sample Collection}

The study sites are located in an industrial estate in Sango Ota, Ogun State, Nigeria, with many manufacturing activities which include pharmaceutical production facilities. With no wastewater treatment plant in sight, production wastewater samples were collected directly from four different pharmaceutical facilities that play key roles in the production and distribution of antibiotics. The samples were untreated wastewater from the production sections held in tanks and subsequently discharged into the public drainage. In one of the sites, wastewater samples were taken from the outlet points in the facility that empty into the public drainage. Table S1 in the supplementary document shows the description of 
sampled sites and samples collected. A total of 8 samples of the untreated wastewater were collected in duplicates from each site in sterile containers and aseptically transported to the laboratory in 2-litre brown glass bottles. The duplicate samples were pooled together to form a composite sample and stored at $4{ }^{\circ} \mathrm{C}$ until processed for isolation of metagenomic DNA. Isolation of genomic genes from antibiotic resistant bacteria and the associated antibiotic resistance genes have been reported in previous works $[3,4]$.

\subsection{Metagenomic DNA Extraction}

Metagenomic DNA were isolated directly from the pharmaceutical wastewater environmental samples using the FastDNA ${ }^{\mathrm{TM}}$ SPIN kit for soil (MP Biomedicals, Solon, $\mathrm{OH}, \mathrm{USA}$ ) according to the manufacturer's instructions, after filtration through a $0.2 \mu \mathrm{L}$ membrane. The process includes the use of the FastPrep instrument for adequate homogenization of the mixture. The concentration and quality of the DNA were determined by the use of NanoDrop ND-1000 (Nanodrop, Foster City, CA, USA). Extracted nucleic acid was stored at $-80^{\circ} \mathrm{C}$ before analysis.

\subsection{Preparation of Oligonucleotide Primers Solutions}

Primers' sequences used in this study were taken from references published in research literatures (Tables S2-S4) in the supplementary document. These standard primer sequence oligonucleotides used were manufactured by Sangon Industries Limited, Beijing, Peoples Republic of China. The primers' sequences are specific for each target gene, with their specific annealing temperature as shown in Tables S2-S4. The forward and reverse sequences are provided separately in dehydrated forms with a stock concentration of $100 \mu \mathrm{M}$. A working laboratory concentration of $20 \mu \mathrm{M}$ was prepared from the stock. The primers solutions were stored under $-20^{\circ} \mathrm{C}$ for PCR analysis.

\subsection{PCR Screening for Antibiotic Resistance Genes and Class 1 integrons}

A total of four wastewaters were screened for ARGs. The detection of specific ARGs encoding resistance was carried out for antibiotics that belong to the classes of tetracycline, aminoglycoside, chloramphenicol, sulphonamides, $\beta$-lactams, and penicillins. In this study, a total of 16 tetracycline (tet) resistance genes were screened in the metagenomic DNA. The tet genes encoding for tetracycline efflux protein tet(A, B, C, D, E, G, J, Y and $\mathrm{Z})$, ribosomal protection protein tet $(\mathrm{BP}, \mathrm{M}, \mathrm{O}, \mathrm{Q}, \mathrm{T}$ and $\mathrm{W})$, and inactivating enzyme (tet $\mathrm{X})$, which frequently appear in various environmental compartments, were screened for. In the screening for aminoglycoside resistance genes, 11 genes conferring resistance to aminoglycoside acetyltransferases (aac(3)-IV, aac(6')-Ib(aacA4), aac(3)-I, aac(3)-II, and

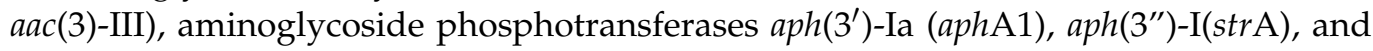
aph(6)-Id(strB), and aminoglycoside nucleotidyltransferases (adenylyltransferases) (ant( $\left.3^{\prime \prime}\right)$ Ia $(\operatorname{aadA})$, ant $(6)-\mathrm{I}(\operatorname{aad} \mathrm{E})$, and $\operatorname{ant}\left(2^{\prime \prime}\right)-\mathrm{Ia}(\operatorname{aadB})$ were screened for in the environmental samples. In the same vein, the presence of 5 clinically important $\beta$-lactam resistance genes (bla) encoding $\beta$-lactamase TEM, NDM-1, OXA, IMP, and CTX-M were screened for. The genes catA1 and cmlA which encode for chloramphenicol acetyltransferases and specific exporters, respectively, were screened for in the DNA; additionally, the presence of 2 sulfonamide resistance genes, sul1 and sul2) were screened for in the metagenomic DNA. The integron 1 (intl1 and intl2), IFS, and Tn15/545 were also investigated in the metagenomic DNA samples.

The isolated metagenomic DNA above were used as the DNA templates for the PCR reaction. PCR reactions were carried out in a $50 \mu \mathrm{L}$ PCR mixture (Takara, Dalian, China), which included $1 \times$ PCR buffer containing $1.5 \mathrm{mM} \mathrm{MgCl}_{2}, 200 \mu \mathrm{M}$ of each deoxynucleoside triphosphate, 10 pmol of each primer, $1.25 \mathrm{U}$ of TaKaRa rTaq polymerase, and $1 \mu \mathrm{L}$ of DNA template. For the negative control in the PCR analysis, $1 \mu \mathrm{L}$ of sterile water was used in place of the DNA templates. The PCR program consists of initial denaturation at $94{ }^{\circ} \mathrm{C}$ for $5 \mathrm{~min}$, followed by 30 cycles of $1 \mathrm{~min}$ at $94{ }^{\circ} \mathrm{C}, 1 \mathrm{~min}$ at different annealing temperatures, extension at $72{ }^{\circ} \mathrm{C}$ for $1 \mathrm{~min}$, and final extension step at $72{ }^{\circ} \mathrm{C}$ for $10 \mathrm{~min}$. The 
specific primers for all the ARGs for each group of antibiotics and their different annealing temperatures for amplification are listed in Tables S2-S6 of the supplementary document. Amplified products were separated by $1.5 \%(\mathrm{wt} / \mathrm{vol})$ agarose gel electrophoresis and visualized under UV light after staining with ethidium bromide.

\section{Results}

\subsection{Antibiotic Resistance Gene Screening}

\subsubsection{Tetracycline Resistance Genes}

Tetracycline resistance (tet) genes were detected in all the pharmaceutical facilities under study (Table 1). A total of $12(75 \%)$ tet genes were detected out of the 16 tet genes screened in all four pharmaceutical facilities (Figure 1). The tetracycline resistance genes encoding efflux proteins were more prevalent than those encoding ribosomal protection proteins and enzymatic modification proteins in the metagenomic DNA samples tested (Table 1). The most common tetracycline resistance gene in the metagenomic DNA samples was tet(G). It was identified in all four facilities studied. This was followed by tet(A), tet(B), tet $(\mathrm{C})$, tet $(\mathrm{D})$, and tet $(\mathrm{X})$ in at least three of the four facilities under study (Table 2). The only tetracycline resistance gene encoding for enzymatic modification proteins detected was tet $(\mathrm{X})$; this was detected in three of the pharmaceutical facilities. Table 1 shows a summary of the resistance gene profile in the metagenomic DNA samples obtained from the pharmaceutical facilities studied, and Figure 1 shows their prevalence. It shows that tet genes were the most prevalent resistance genes screened for. Metagenomic DNA that carried more than two kinds of tet gene were common, but tet(E), tet (L), and tet(30) were detected in only one facility. The pharmaceutical facility PFI has the highest prevalence of tetracycline resistance genes in this study; a total of $9(56.3 \%)$ tet genes were detected of the 16 screened in this study (Figure 1). The tet genes encountered in the facility are shown in Table 2.

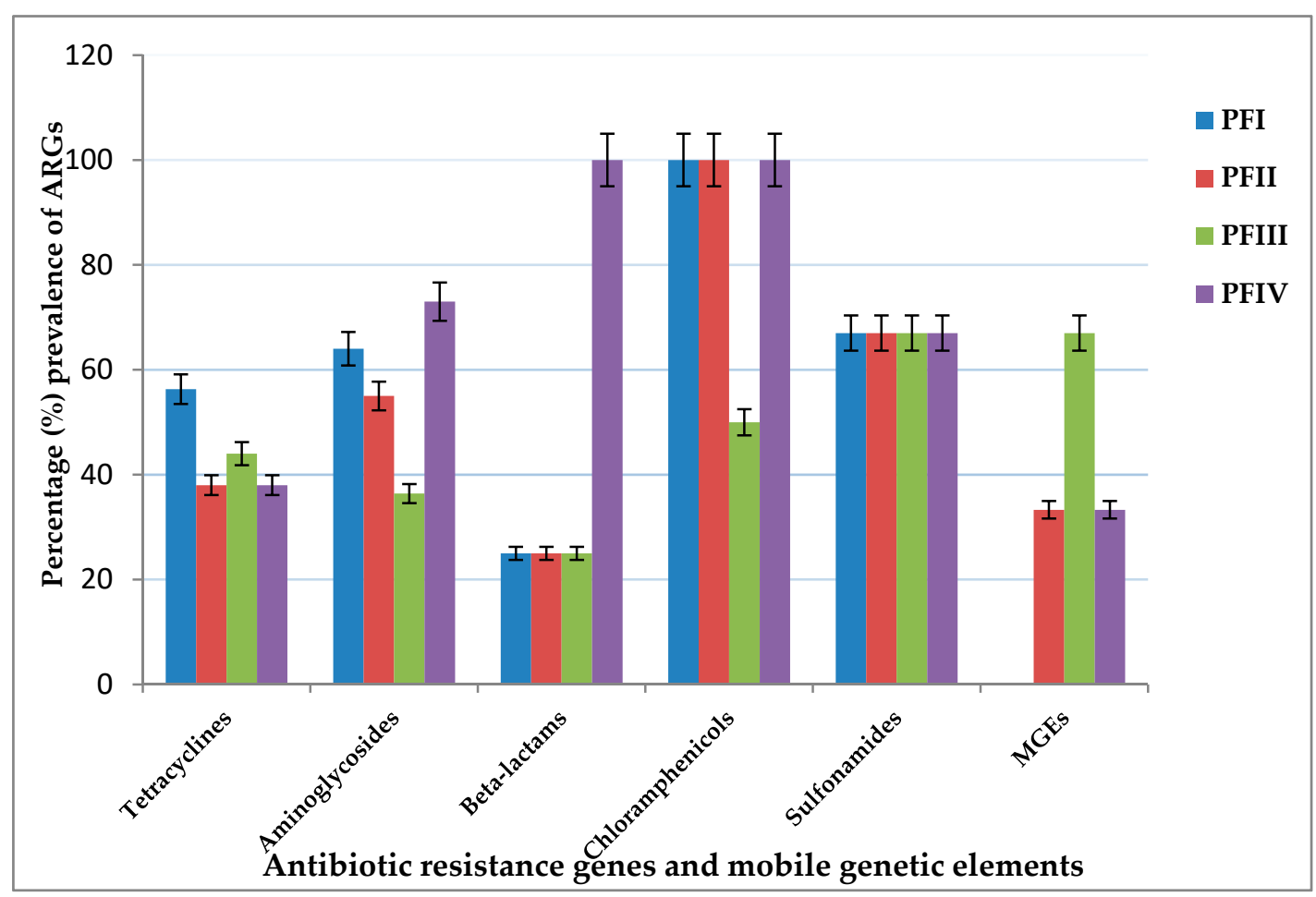

Figure 1. Percentage ARGs and integrons tested positive in metagenomic DNA samples obtained from pharmaceutical wastewaters. 
Table 1. Distribution of selected antibiotics resistance genes from pharmaceutical wastewater.

\begin{tabular}{|c|c|c|c|c|c|c|}
\hline \multirow{2}{*}{$\begin{array}{c}\text { Gene } \\
\text { Function/Mechanism of } \\
\text { Drug Resistance }\end{array}$} & \multirow{2}{*}{$\begin{array}{l}\text { Resistance } \\
\text { Genes }\end{array}$} & \multicolumn{4}{|c|}{ Pharmaceutical Facility } & \multirow{2}{*}{$\begin{array}{c}\text { Total No. of } \\
\text { Facilities with } \\
\text { Positive Genes } \\
\end{array}$} \\
\hline & & PFI & PFII & PFIII & PFIV & \\
\hline \multirow{7}{*}{ Efflux } & tet(A) & + & + & + & - & 3 \\
\hline & tet $(\mathrm{B})$ & + & - & + & + & 3 \\
\hline & $\operatorname{tet}(\mathrm{C})$ & + & - & + & + & 3 \\
\hline & tet(D) & + & + & + & - & 3 \\
\hline & tet $(\mathrm{E})$ & - & - & - & + & 1 \\
\hline & $\operatorname{tet}(\mathrm{G})$ & + & + & + & + & 4 \\
\hline & tet $(30)$ & - & - & - & + & 1 \\
\hline \multirow{3}{*}{ Ribosomal Protection } & $\operatorname{tet}(\mathrm{L})$ & + & - & - & - & 1 \\
\hline & tet $(\mathrm{M})$ & - & + & + & - & 2 \\
\hline & $\operatorname{tet}(\mathrm{Q})$ & + & - & + & - & 2 \\
\hline \multirow{2}{*}{ Enzymatic modification } & $\operatorname{tet}(\mathrm{BP})$ & + & + & - & - & 2 \\
\hline & $\operatorname{tet}(\mathrm{X})$ & + & + & - & + & 3 \\
\hline \multirow{3}{*}{ Acetyl transferases } & $\operatorname{aac}(3)-\mathrm{II}$ & + & + & - & + & 3 \\
\hline & $\operatorname{aac}(3)-\mathrm{IV}$ & + & + & - & + & 3 \\
\hline & aacA4 & - & - & - & + & 3 \\
\hline \multirow{3}{*}{ Nucleotidyl-transferases } & $\operatorname{aadA}$ & + & + & + & + & 4 \\
\hline & $\operatorname{aadB}$ & + & - & + & + & 3 \\
\hline & $\operatorname{aph} \mathrm{A} 1$ & + & + & - & + & 3 \\
\hline \multirow{2}{*}{ Phosphor-transferases } & strA & + & + & + & + & 4 \\
\hline & strB & + & + & + & + & 4 \\
\hline \multirow{4}{*}{$\beta$-Lactamase } & $b l a_{\mathrm{TEM}}$ & - & - & - & + & 1 \\
\hline & $b l a_{\mathrm{OXA}}$ & + & + & + & + & 4 \\
\hline & $b l a_{\mathrm{CTX}-\mathrm{M}}$ & - & - & - & + & 1 \\
\hline & $b l a_{\mathrm{IMP}}$ & - & - & - & + & 1 \\
\hline \multirow{2}{*}{$\begin{array}{l}\text { Chloramphenicol } \\
\text { acetyltransferase }\end{array}$} & catA1 & + & + & + & + & 4 \\
\hline & cmlA & + & + & - & + & 3 \\
\hline \multirow{2}{*}{ Dihydropteroate synthase } & sulI & + & + & + & + & 4 \\
\hline & sulII & + & + & + & + & 4 \\
\hline \multirow{2}{*}{ Integrase } & Intl1 & - & + & + & + & 3 \\
\hline & Intl2 & - & - & + & - & 1 \\
\hline
\end{tabular}

Table 2. Antibiotic resistance genes and mobile genetic elements from metagenomic genes obtained from pharmaceutical facilities' wastewaters.

\begin{tabular}{|c|c|c|c|c|}
\hline * Pharmaceutical Facilities & PFI & PFII & PFIII & PFIV \\
\hline Sources & WWHT & WWHT & WWHT & WWDP \\
\hline Tetracycline Resistance Genes & $\begin{array}{l}\operatorname{tet}(\mathrm{A}), \operatorname{tet}(\mathrm{B}), \operatorname{tet}(\mathrm{C}), \\
\operatorname{tet}(\mathrm{D}), \operatorname{tet}(\mathrm{G}), \operatorname{tet}(\mathrm{L}), \\
\operatorname{tet}(\mathrm{Q}), \operatorname{tet}(\mathrm{X}), \operatorname{tet}(\mathrm{BP})\end{array}$ & $\begin{array}{l}\operatorname{tet}(\mathrm{A}), \operatorname{tet}(\mathrm{D}), \operatorname{tet}(\mathrm{G}) \\
\text { tet }(\mathrm{M}), \operatorname{tet}(\mathrm{X}) \text { tet }(\mathrm{BP})\end{array}$ & $\begin{array}{l}\operatorname{tet}(\mathrm{A}), \operatorname{tet}(\mathrm{B}), \operatorname{tet}(\mathrm{C}) \\
\operatorname{tet}(\mathrm{D}), \operatorname{tet}(\mathrm{G}), \operatorname{tet}(\mathrm{M}) \\
\operatorname{tet}(\mathrm{Q})\end{array}$ & $\begin{array}{l}\operatorname{tet}(\mathrm{B}), \operatorname{tet}(\mathrm{C}), \operatorname{tet}(\mathrm{E}), \\
\text { tet }(\mathrm{G}), \operatorname{tet}(\mathrm{X}), \operatorname{tet}(30)\end{array}$ \\
\hline Aminoglycoside Resistance Genes & $\begin{array}{c}\text { aadA, aadB, aac(3)-II, } \\
\text { aac(3)-IV, aph A1, } \\
\text { strA, strB }\end{array}$ & $\begin{array}{l}\text { aad A, aac(3)-II, } a a c(3)-\mathrm{IV}, \\
\text { aphA1, strA, strB }\end{array}$ & $\operatorname{aad} \mathrm{A}, \operatorname{aad} \mathrm{B}, \operatorname{str} \mathrm{A}, \operatorname{str} \mathrm{B}$ & $\begin{array}{c}\operatorname{aad\mathrm {A},} \text { aadB, aac(3)-II, } \\
\operatorname{aac}(3)-\mathrm{IV}, \text { aph } \mathrm{A} 1, \operatorname{aacA} 4, \\
\text { strA, strB }\end{array}$ \\
\hline$\beta$-Lactams Resistance Genes & $b l a_{\mathrm{OXA}}$ & $b l a_{\mathrm{OXA}}$ & $\begin{array}{l}b l a_{\mathrm{TEM}}, b l a_{\mathrm{OXA}}, \\
b l a_{\mathrm{TT}}, b l a_{\mathrm{TP}}\end{array}$ & $b l a_{\mathrm{OXA}}$ \\
\hline $\begin{array}{l}\text { Chloramphenicol Resistance Genes } \\
\text { Sulphonamide Resistance Genes } \\
\text { Mobile Genetic Elements }\end{array}$ & $\begin{array}{l}\text { catA1, cmlA } \\
\text { sulI, sulII } \\
-\end{array}$ & $\begin{array}{l}\text { catA1, cmlA } \\
\text { sulI, sulII } \\
\text { intl1 }\end{array}$ & $\begin{array}{l}\text { catA1 } \\
\text { sulI, sulII } \\
\text { intl1, intl2, }\end{array}$ & $\begin{array}{l}\text { catA1, cmlA } \\
\text { sulI, sulII } \\
\text { intl1 }\end{array}$ \\
\hline
\end{tabular}

* PF: Pharmaceutical Facility; WWHT: Wastewater Holding Tank; WWDP: Wastewater Discharge Point; MGEs: Mobile Genetic Elements.

\subsubsection{Aminoglycoside Resistance Genes}

The prevalence of aminoglycoside resistance genes obtained from the wastewater of the pharmaceutical facilities is as shown in Figure 1. Metagenomic DNA that carried at least three kinds of aminoglycoside resistance genes were common. A total of 8 (73\%) aminoglycoside resistance genes were detected out of the 11 screened for in all the four 
pharmaceutical facilities (Figure 1). The aminoglycoside resistance genes, aadA, encoding nucleotidyltransferase enzymes were the most abundant aminoglycoside resistance gene in the metagenomic DNA samples, with prevalence in all four pharmaceutical facilities studied. The acetyltransferase encoding gene, aacA4, was prevalent in only one site, PFIV (Table 1). The pharmaceutical facility PFIV had the highest number of aminoglycoside resistance genes in this study, a total of $8(73 \%)$ genes that confer resistance to aminoglycoside genes were detected of the 11 genes screened in this study (Figure 1).

\subsection{3. $\beta$-Lactams and Penicillin Resistance Genes}

The genes $(b l a)$ that confer resistance to $\beta$-Lactams and penicillin were detected in all the pharmaceutical facilities studied (Table 2). Four different bla genes were detected out of the five screened for in the facilities. The most prevalent $\beta$-Lactams and penicillin resistance (bla) gene in the metagenomic DNA was bla ${ }_{\mathrm{OXA}}$, identified in the four facilities. The other $\beta$-lactamase encoding genes, $b l a_{\mathrm{TEM}}, b l a_{\mathrm{CTX}-\mathrm{M}}$, and $b l a_{\mathrm{IMP}}$, detected in the study were observed in only one facility site (Table 1 ). The pharmaceutical facility PFIV showed the highest occurrence of $\beta$-Lactams and penicillin resistance genes in this study, positive for four bla genes out of the five screened (Table 1). The bla genes encountered in this facility are shown in Table 1 . The $\beta$-Lactamase encoding gene, $b l a_{\mathrm{NDM}-1}$, was not detected in any of the metagenomic DNA samples screened.

\subsubsection{Chloramphenicol and Sulfonamides Resistance Genes}

Chloramphenicol resistance genes were detected in the four pharmaceutical facilities studied (Table 1). The two chloramphenicol resistance genes, cat A1 and $c m l \mathrm{~A}$, were the only two resistance genes to chloramphenicol screened for in the study. The result revealed a high prevalence of both genes (Figure 1) in the metagenomic DNA samples obtained from the wastewaters. The genes cat A1 and $\mathrm{cmlA}$ were present in three of the four facilities that were studied, but cat A1 genes were present in all the metagenomic DNA samples obtained from the facilities (Table 1). The pharmaceutical facilities PFI, PFII, and PFIV were screened positive for all the chloramphenicol resistance genes in the study. The sulfonamides resistance genes $(\mathrm{sul})$ were detected in all the pharmaceutical facilities under study (Table 1). The sulfonamides resistance genes, sulI and sulII, were detected in the four pharmaceutical facilities studied, but sulIII genes were not detected in any of the facilities (Table 2).

\subsubsection{Mobile Genetic Elements}

The pharmaceutical facilities showed the prevalence of at least one mobile genetic element (MGEs) except for PFI (Table 1). The mobile genetic elements, integron class I (Intl1) and class II (Intl2), and the transposon Tn15/545 were screened for in the metagenomic DNA samples. The intl1 genes were identified in three of the four pharmaceutical sites screened, but Intl2 genes were detected only in one of the facilities. The pharmaceutical facility PFI did not show prevalence for any of the MGEs screened for; PFII was positive for intl1 genes; PFIII showed the highest occurrence of the MGEs, positive for intl1, and intl2 genes; and PFIV showed prevalence for intl1 genes (Figure 1). Aminoglycoside resistance gene groups found in the integron cassettes have been discussed above (Table 1). The transposon Tn15/545 was not detected in any of the facilities.

\section{Discussion}

In this study, primers of known genes were used to study the prevalence of ARGs in metagenomic DNA samples extracted from pharmaceutical production wastewaters. The antibiotic resistance gene profiles of the metagenomic DNA samples were diverse compared to similar works carried out on genomic DNA samples from the same environment $[3,4]$. Whereas this study provides an opportunity to highlight relevant research in a data-scarce context, the limitation in this study was the difficulty encountered during sample collection, which limited the number of samples available in the study. This was 
a result of the non-compliance of facility owners to the study. Nonetheless, our findings demonstrated that ARGs and MGEs are present in the wastewaters, which are likely to enter the waterways. This was a complementary result to the outcome of our earlier studies mentioned above $[3,4]$.

Our results indicate that ARGs and MGEs were widely distributed in the environmental samples. The pharmaceutical facility PFIV showed the highest prevalence of ARGs in this study (Figure 1). This facility was the only pharmaceutical factory in the study that lacked both a wastewater treatment plant and a holding tank. Wastewaters from the facility were directly channeled to the public drain from the production area. The point where the facility wastewater (effluent) enters the public drain was sampled repeatedly. This facility was positive for 24 ARGs and MGEs screened for in the study (Table 1). It showed the highest prevalence for aminoglycoside resistance genes. This finding suggests that the public drain and receiving river waters have become potential points for the development of antibiotic resistance and hotspots for horizontal gene transfer (HGT) in the environment. Recent studies have established the fact that even a trace of antibiotics or other pharmaceuticals in wastewaters can cause selection pressure for antibiotics resistance $[6,26,27]$.

The presence of tetracycline and tetracycline resistance genes (tet) have been reported in wastewaters, as well as other environmental compartments $[4,28,29]$. The pharmaceutical facility PFI showed the highest occurrence of tetracycline resistance genes in this study (Table 1). Our results show that the genes encoding for efflux protein were the most abundant in this study, like in most environmental tet genes that code for transport proteins [30]. The efflux gene tet $(\mathrm{G})$ was the most prevalent of the tet genes, occurring in all the metagenomic DNA samples (Table 1). However, it was not detected in any of the genomic DNA samples extracted from 60 bacterial isolates from the same environment in a previous report [4]. All the tet genes encoding ribosomal protection proteins screened in this research were positive except for $\operatorname{tet}(\mathrm{T})$. The enzyme modification gene $\operatorname{tet}(\mathrm{X})$ was the only tet gene detected in this category in three of the four facilities in the study (Table 1). The dissemination of tet $(\mathrm{X})$ resistance gene is of special concern because it also confers resistance against the third-generation tetracycline, tigecycline [31]. Although the use of tigecycline is strictly regulated, $\operatorname{tet}(\mathrm{X})$ has already been reported in pathogenic bacteria [12] and about $5 \%$ of bacterial isolates in our previous study [4].

The direct deactivation of aminoglycoside by modifying enzymes located in perisplasmic space is a major mechanism of action of aminoglycoside resistance genes [32]. In this study, aminoglycoside resistance genes encoding for three transferase enzymes, acetyltransferases (AAC), nucleotidyltransferases (ANT), and phosphotransferases (APH), responsible for the inactivation of aminoglycoside, were detected. The pharmaceutical facility PFIV showed the highest presence of aminoglycoside resistance genes in the study. In the metagenomic DNA, aminoglycoside resistance genes were detected in all the study sites. They were positive for at least four of the aminoglycoside resistance genes screened for. The nucleotidyltransferases encoding gene, aad $\mathrm{A}$, and the phosphotransferases encoding genes, str $\mathrm{A}$ and $s t r \mathrm{~B}$, showed the highest occurrence of the aminoglycoside resistance genes (Table 1). Though the metagenomic DNA samples showed the presence of several aminoglycoside resistance genes, reports of several works on the aminoglycoside resistance gene show that the genes of aac $\mathrm{C} 1, \mathrm{C} 2, \mathrm{C} 3$, and C4, encoding aminoglycoside$3-\mathrm{N}$-acetyltransferase, were often detected in microbial communities or isolates from STPs [33-35].

Resistance to beta-lactams antibiotics usually occurs via hydrolysis of the beta-lactam ring mediated by a wide range of beta-lactamases [36], produced by resistant strains capable of inactivating beta-lactam drugs. Although beta-lactams, especially penicillins, are the most commonly used antimicrobial agents, they are relatively rarely detected in wastewater and activated sludge samples [37-40]. Despite this, the pharmaceutical facility PFIV showed a high prevalence of $b l a_{\mathrm{OXA}}, b l a_{\mathrm{TEM}}, b l a_{\mathrm{IMP}}$, and $b l a_{\mathrm{CTX}-\mathrm{M}}$, with $b l a_{\mathrm{OXA}}$ showing the highest prevalence (Figure 1). This result conforms to findings in similar 
studies within WWTPs, where bla $\mathrm{OXA}-58$, beta-lactamase genes that confer resistance to carbapenems [41], were frequently reported [42-44]. Other pharmaceutical sites in this study showed the presence of only one bla gene. The beta-lactamases resistance gene, $b l a_{\mathrm{NDM}-1}$, was not detected in any of the sites, but detected in a similar study using genomic DNA from bacterial isolates obtained from the same sites but not from the same samples (4).

Chloramphenicol acetyltransferases (catA1) and specific exporters ( $c m l A)$ were the common mechanisms responsible for resistance to chloramphenicol antibiotics detected in the facilities. Our findings indicate that catA1 and $c m l \mathrm{~A}$ were widely distributed among the environmental samples, with catA1 detected in all the pharmaceutical facilities studied. In addition, $\mathrm{cmlA}$ was positive in all the study sites except in facility PFIII (Table 1), which is prevalent in catA1. This result conforms to our findings in genomic DNA of bacterial isolates where catA1 and $c m l$ A were widely distributed among the environmental bacterial isolates, with catA1 genes more frequently detected in the genomes of several species than the cmlA (3). In addition, catA1 and cmlA have been reported in several studies [45-47] in different environmental compartments.

The mechanisms of resistance to sulfonamides are diverse [48] and sulI, sulII, and sulIII genes, coding dihydropteroate synthase (DHPS) with lower affinity to sulfonamides, are mainly responsible for the resistance to sulfonamides. These genes are found on MGEs, both transposons and plasmids, in many different species of bacteria [49]. In this study, metagenomic DNA samples were screened for sulfonamides resistance genes, sul1 and sul2. Our result shows a very high prevalence for both genes. They were widely distributed among the environmental samples; both genes were detected in all the metagenomic DNA samples. This group of resistance genes were the only ARGs that were common to all the pharmaceutical facilities in this study. Contrary to this, sul1 and sul2 resistance genes were not detected in all the bacterial isolates from the same environment, but different samples [3]. About $31.7 \%$ and $21.7 \%$ of sul1 and sul2 were detected in the genomic DNA of the bacterial isolates, respectively (3). Various reports demonstrated the presence of sulfonamide resistance genes in WWTPs, especially in activated sludge where sulfonamide and tetracycline resistant bacteria and genes were identified and discharged into the water environment [50,51]. These genes were present at higher rates in effluent compared to the influent at the end of treatment in WWTPs [52]. This is a worrisome situation, considering the wide application of these different classes of antibiotics.

In our previous report, ARG-related MGEs were identified in cultured antibiotic resistant bacteria from the same pharmaceutical facilities [4]. MGEs, such as plasmids, transposons, and integrons, have been implicated in possible horizontal gene transfer of ARGs among bacteria with the same or different origins [8]. In this study, class I (Intl1) and class II (Intl2) integrons were prevalent in three pharmaceutical facilities under study (Figure 1). The metagenomic DNA samples from these facilities showed prevalence for at least one MGE, except for PF1. The facility PFIII has the greatest prevalence of MGEs (Table 1). It was the only facility that was positive for Intl2. The presence of the MGEs in these facilities that lack wastewater treatment plants is very worrisome, particularly with their indiscriminate discharge of wastewaters into the public drains. There, the possibility of ARGs transferred to the environmental bacteria community within the receiving water bodies is very high. Even in the cases of effluents from functional WTPs, there have been reports of a high prevalence of MGEs. Though in some cases there is a significant reduction in their concentrations, their presence is still reported with the potential to transfer ARGs [20]. Hence, there is a need to pass wastewater through a functional wastewater treatment plant. The process should involve at least a secondary treatment before being discharged into water bodies or public drains. In the case of water reuse, treatment can be extended to the tertiary level, as the case may be.

\section{Conclusions}

Our findings indicate that pharmaceutical wastewater may play a significant role in the emergence of ARGs and MGEs. The approach employed was able to reveal the 
presence of diverse ARGs and MGEs in the different pharmaceutical facilities. The PCRbased method amplifying the metagenomic DNA was sensitive and provided a relatively rapid result compared to genomic DNA amplification in our previous study [4]. Generally, PCR-based analysis on antibiotic resistance in environmental samples is faced with many biases, and this is not limited to nonspecific reactions. In our future reports, a more specific analysis, quantitative PCR, will be provided for some selected resistance genes. Our findings confirmed that ARGs and MGE reported in the genomic DNA [4] are present in these environments. The different MGEs reported in this study may be responsible for horizontal gene transfers of ARGs within these environments. To prevent the spread of ARB and ARGs, the wastewaters produced from these facilities should be passed through a wastewater treatment plant, and the sewage sludge produced by this WWTP should be treated through dewatering and incineration. The regulatory authorities in these areas should embrace the challenge for more sustainable living for the populace.

Supplementary Materials: The following are available online at https:/ /www.mdpi.com/article / 10.3390/w13131731/s1, Table S1: Description of sites and sources of metagenomic DNA of Pharmaceutical wastewater, Table S2: Primers and conditions used to amplify tetracycline resistance genes by the PCR techniques, Table S3: Primers and conditions used to amplify aminoglycosides resistance genes by PCR techniques, Table S4: Primers and conditions used to amplify $\beta$-Lactam resistance genes by PCR techniques, Table S5: Primers and conditions used to amplify sulphonamide and chloramphenicol resistance genes by PCR technique, Table S6: Primers and conditions used to amplify some genetic elements by PCR technique.

Author Contributions: Conceptualization, A.O. (Amarachukwu Obayiuwana); methodology, A.O. (Amarachukwu Obayiuwana), A.O. (Adeniyi Ogunjobi), and A.I.; software, A.I.; validation, A.O. (Amarachukwu Obayiuwana) and A.O. (Adeniyi Ogunjobi); formal analysis, A.O. (Amarachukwu Obayiuwana); investigation, A.O. (Amarachukwu Obayiuwana) and A.O. (Adeniyi Ogunjobi); resources, A.O. (Amarachukwu Obayiuwana), A.O. (Adeniyi Ogunjobi), and A.I.; data curation, A.O. (Amarachukwu Obayiuwana); writing-original draft preparation, A.O. (Amarachukwu Obayiuwana); writing-review \& editing, A.O. (Amarachukwu Obayiuwana), A.O. (Adeniyi Ogunjobi), and A.I.; visualization, A.I.; supervision, A.O. (Adeniyi Ogunjobi) and A.I.; project administration, A.O. (Amarachukwu Obayiuwana), A.O. (Adeniyi Ogunjobi), and A.I.; funding acquisition, A.O. (Amarachukwu Obayiuwana) and A.I. All authors have read and agreed to the published version of the manuscript.

Funding: This research was funded by Organization for Women in Science for the Developing World, grant number 3240266476. The APC was funded by co-author, Abasiofiok Ibekwe.

Institutional Review Board Statement: Not Applicable.

Informed Consent Statement: Not Applicable.

Data Availability Statement: Not Applicable.

Acknowledgments: This work was sponsored by the Organization for Women in Science for the developing world (OWSD) and The State Key Laboratory of Environmental Aquatic Chemistry, Research Center for Eco-Environmental Sciences, Chinese Academy of Science.

Conflicts of Interest: The authors declare no conflict of interest.

\section{References}

1. Pruden, A. Balancing water sustainability and public health goals in the face of growing 650 concerns about antibiotic resistance. Environ. Sci. Technol. 2014, 48, 5-14. [CrossRef] [PubMed]

2. Berendonk, T.U.; Manaia, C.M.; Merlin, C.; Fatta-Kassinos, D.; Cytryn, E.; Walsh, F.; Bürgmann, H.; Sørum, H.; Norström, M.; Pons, M.N.; et al. Tackling antibiotic resistance: The environmental framework. Nat. Rev. Microbiol. 2015, 13, 310-317. [CrossRef] [PubMed]

3. Obayiuwana, A.C.; Ogunjobi, A.; Yang, M.; Ibekwe, M. Characterization of bacterial communities and their antibiotic resistance profiles in wastewaters obtained from pharmaceutical facilities in Lagos and Ogun States, Nigeria. Int. J. Environ. Res. Public Health 2018, 15, 1365-1378. [CrossRef]

4. Obayiuwana, A.C.; Ibekwe, A.M. Antibiotic resistance genes occurrence in wastewaters from selected pharmaceutical facilities in Nigeria. Water 2020, 15, 1897. [CrossRef] 
5. Thakali, O.; Brooks, J.P.; Shahin, S.; Sherchan, S.P.; Haramoto, E. Removal of Antibiotic Resistance Genes at Two Conventional Wastewater Treatment Plants of Louisiana, USA. Water 2020, 12, 1729. [CrossRef]

6. Karkman, A.; Do, T.T.; Walsh, F.; Virta, M.P.J. Antibiotic-resistance genes in waste water-review. Trends Microbiol. 2017, 26, 220-228. [CrossRef]

7. Moles, S.; Mosteo, R.; Gómez, J.; Szpunar, J.; Gozzo, S.; Castillo, J.R.; Ormad, M.P. Towards the Removal of Antibiotics Detected in Wastewaters in the POCTEFA Territory: Occurrence and TiO2 Photocatalytic Pilot-Scale Plant Performance. Water 2020, $12,1453$. [CrossRef]

8. Li, L.; Guo, C.; Fan, S.; Lv, J.; Zhang, Y.; Xu, Y.; Xu, J. Dynamic transport of antibiotics and antibiotic resistance genes under different treatment processes in a typical pharmaceutical wastewater treatment plant. Environ. Sci. Pollut. Res. 2018, 25, 30191-30198. [CrossRef]

9. Watkinson, A.J.; Micalizzi, G.B.; Graham, G.M.; Bates, J.B.; Costanzo, S.D. Antibiotic resistant Escherichia coli in wastewaters, surface waters, and Oysters from an urban riverine system. Appl. Environ. Microbiol. 2007, 73, 5667-5670. [CrossRef]

10. Allen, H.K.; Donato, J.; Wang, H.H.; Cloud-Hansen, K.A.; Davies, J.; Handelsman, J. Call of the wild: Antibiotic resistance genes in natural environments. Nat. Rev. Microbiol. 2010, 8, 251-259. [CrossRef]

11. Munck, C.; Albertsen, M.; Telke, A.; Ellabaan, M.; Nielsen, P.H.; Sommer, M.O. Limited dissemination of the wastewater treatment plant core resistome. Nat. Commun. 2015, 6, 8452. [CrossRef] [PubMed]

12. Aminov, R.I. Evolution in action: Dissemination of tet(x) into pathogenic microbiota. Front. Microbiol. 2013, 4. [CrossRef]

13. Jiang, X.; Cui, X.; Xu, H.; Liu, W.; Tao, F.; Shao, T.; Pan, X.; Zheng, B. Whole genome sequencing of Extended-Spectrum BetaLactamase (ESBL)-producing Escherichia coli isolated from a wastewater treatment plant in China. Front. Microbiol. 2019, 10, 1797. [CrossRef]

14. Zhang, X.X.; Zhang, T. Occurrence, abundance, and diversity of tetracycline resistance genes in 15 sewage treatment plants across china and other global locations. Environ. Sci. Technol. 2011, 45, 2598-2604. [CrossRef] [PubMed]

15. Liu, M.; Zhang, Y.; Yang, M.; Tian, Z.; Ren, L.; Zhang, S. Abundance and distribution of tetracycline resistance genes and mobile elements in an oxytetracycline production wastewater treatment system. Environ. Sci. Technol. 2012, 46, 7551-7557. [CrossRef]

16. Walsh, F.; Duffy, B. The culturable soil antibiotic resistome: A community of multi-drug resistant bacteria. PLoS ONE 2014, e65567. [CrossRef]

17. Schmiede, R.; Edwards, R. Insights into antibiotic resistance through metagenomic approaches. Future Microbiol. 2012, 7, 73-89. [CrossRef] [PubMed]

18. Yang, Y.; Li, B.; Zou, S.; Fang, H.H.P.; Zhang, T. Fate of antibiotic resistance genes in sewage treatment plant revealed by metagenomic approach. Water Res. 2014, 62, 97-106. [CrossRef]

19. Zankari, E.; Hasman, H.; Cosentino, S.; Vestergaard, M.; Rasmussen, S.; Lund, O.; Aarestrup, F.M.; Larsen, M.V. Identification of acquired antimicrobial resistance genes. J. Antimicrob. Chemother. 2012, 67, 2640-2644. [CrossRef]

20. Gupta, S.K.; Padmanabhan, B.R.; Diene, S.M.; Lopez-Rojas, R.; Kempf, M.; Landraud, L.; Rolain, J.M. ARG-ANNOT, a New bioinformatic tool to discover antibiotic resistance genes in bacterial genomes. Antimicrob. Agents Chemother. 2014, 58, 212-220. [CrossRef]

21. Jia, B.; Raphenya, A.R.; Alcock, B.; Waglechner, N.; Guo, P.; Tsang, K.K.; Lago, B.A.; Dave, B.M.; Pereira, S.; Sharma, A.N.; et al. CARD 2017: Expansion and model-centric curation of the comprehensive antibiotic resistance database. Nucleic Acids Res. 2016, 45, gkw1004. [CrossRef]

22. Guo, J.; Li, J.; Chen, H.; Bond, P.; Yuan, Z. Metagenomic analysis reveals wastewater treatment plants as hotspots of antibiotic resistance genes and mobile genetic elements. Water Res. 2017, 7, 002. [CrossRef]

23. Nesme, J.; Cécillon, S.; Delmont, T.O.; Monier, J.M.; Vogel, T.M.; Simonet, P. Large-scale metagenomic-based study of antibiotic resistance in the environment. Curr. Biol. 2014, 24, 1096-1100. [CrossRef] [PubMed]

24. Li, B.; Yang, Y.; Ma, L.; Ju, F.; Guo, F.; Tiedje, J.M.; Zhang, T. Metagenomic and network analysis reveal wide distribution and co-occurrence of environmental antibiotic resistance genes. ISME J. 2015, 9, 2490-2502. [CrossRef] [PubMed]

25. Yang, Y.; Li, B.; Ju, F.; Zhang, T. Exploring variation of antibiotic resistance genes in activated sludge over a four-year period through a metagenomic approach. Environ. Sci. Technol. 2013, 47, 10197-10205. [CrossRef] [PubMed]

26. Sandegren, L. Selection of antibiotic resistance at very low antibiotic concentrations. Upsala J. Med. Sci. 2014, 119, 103-107. [CrossRef]

27. Lundström, S.V.; Östman, M.; Bengtsson-Palme, J.; Rutgersson, C.; Thoudal, M.; Sircar, T.; Blanck, H.; Eriksson, K.M.; Tysklind, M.; Flach, C.; et al. Minimal selective concentrations of tetracycline in complex aquatic bacterial biofilms. Sci. Total Environ. 2016, 553, 587-595. [CrossRef] [PubMed]

28. Chen, G.; Zhao, L.; Dong, Y.H. Oxidative degradation kinetics and products of chlortetracycline by manganese dioxide. J. Hazard. Mater. 2011, 193, 128-138. [CrossRef] [PubMed]

29. Li, R.; Zhang, Y.; Lee, C.C.; Liu, L.; Huang, Y. Hydrophilic interaction chromatography separation mechanisms of tetracyclines on amino-bonded silica column. J. Sep. Sci. 2011, 34, 1508-1516. [CrossRef]

30. Roberts, M.C. Resistance to tetracycline, macrolide-lincosamide-streptogramin, trimethoprim, and sulfonamide drug classes. Mol. Biotechnol. 2002, 20, 261-283. [CrossRef]

31. Moore, I.F.; Hughes, D.W.; Wright, G.D. Tigecycline is modified by the flavin-dependent monooxygenase tet(x). Biochemistry. 2005, 44, 11829-11835. [CrossRef] 
32. Shakil, S.; Khan, R.; Zarrilli, R.; Khan, A.U. Aminoglycosides versus bacteria-A description of the action, resistance mechanism, and nosocomial battle ground. J. Biomed. Sci. 2008, 15, 5-14. [CrossRef]

33. Heuer, H.; Krögerrecklenfort, E.; Wellington, E.M.H.; Egan, S.; van Elsas, J.D.; van Overbeek, L.; Collard, J.M.; Guillaume, G.; Karagouni, A.D.; Nikolakopoulou, T.L.; et al. Gentamicin resistance genes in environmental bacteria: Prevalence and transfer. FEMS Microbiol. Ecol. 2002, 42, 289-302. [CrossRef]

34. Tennstedt, T.; Szczepanowski, R.; Braun, S.; Pühler, A.; Schlüter, A. Occurrence of integron-associated resistance gene cassettes located on antibiotic resistance plasmids isolated from a wastewater treatment plant. FEMS Microbiol. Ecol. 2003, 45, 239-252. [CrossRef]

35. Tennstedt, T.; Szczepanowski, R.; Krahn, I.; Pühler, A.; Schlüter, A. Sequence of the 68,869 bp IncP-1a plasmid pTB11 from a wastewater treatment plant reveals a highly conserved backbone, a Tn402-like integron and other transposable elements. Plasmid 2005, 53, 218-238. [CrossRef]

36. Livermore, D.M. Are all beta-lactams created equal? Scand. J. Infect. Dis. Suppl. 1996, 101, 33-43. [PubMed]

37. Craig, W.A. Basic pharmacodynamics of antibacterials with clinical applications to the use of $\beta$-lactams, glycopeptides, and linezolid. Infect. Dis. Clin. N. Am. 2003, 17, 479-501. [CrossRef]

38. Benito-Peña, E.; Partal-Rodera, A.I.; León-González, M.E.; Moreno-Bondi, M.C. Evaluation of mixed mode solid phase extraction cartridges for the preconcentration of beta-lactam antibiotics in wastewater using liquid chromatography with UV-DAD detection. Anal. Chim. Acta 2006, 556, 415-422. [CrossRef]

39. Brown, K.D.; Kulis, J.; Thomson, B.; Chapman, T.H.; Mawhinney, D.B. Occurrence of antibiotics in hospital, residential, and dairy effluent, municipal wastewater, and the Rio Grande in New Mexico. Sci. Total Environ. 2006, 366, 772-783. [CrossRef]

40. Bailón-Pérez, M.I.; García-Campaña, A.M.; Cruces-Blanco, C.; del Olmo Iruela, M. Trace determination of $\beta$-lactam antibiotics in environmental aqueous samples using off-line and on-line preconcentration in capillary electrophoresis. J. Chromatogr. 2008, 1185, 273-280. [CrossRef]

41. Poirel, L.; Marque, S.; Heritier, C.; Segonds, C.; Chabanon, G.; Nordmann, P. OXA-58, a novel class D \{beta\}-lactamase involved in resistance to carbapenems in Acinetobacter baumannii. Antimicrob. Agents Chemother. 2005, 49, 202-208. [CrossRef] [PubMed]

42. Caucci, S.; Karkman, A.; Cacace, D.; Rybicki, M.; Timpel, P.; Voolaid, V.; Gurke, R.; Virta, M.; Berendonk, T.U. Seasonality of antibiotic prescriptions for outpatients and resistance genes in sewers and wastewater treatment plant outflow. FEMS Microbiol. Ecol. 2016, 92, fiw060. [CrossRef] [PubMed]

43. Karkman, A.; Johnson, T.A.; Lyra, C.; Stedtfeld, R.D.; Tamminen, M.; Tiedje, J.M.; Virta, M. High-throughput quantification of antibiotic resistance genes from an urban wastewater treatment plant. FEMS Microbiol. Ecol. 2016, 92. [CrossRef] [PubMed]

44. Hultman, J.; Tamminen, M.; Pärnänen, K.; Cairns, J.; Karkman, A.; Virta, M. Host range of antibiotic resistance genes in wastewater treatment plant influent and effluent. FEMS Microbiol. Ecol. 2018, 94, 1-10. [CrossRef] [PubMed]

45. Schwarz, S.; Kehrenberg, C.; Doublet, B.; Cloeckaert, A. Molecular basis of bacterial resistance to chloramphenicol and florfenicol. FEMS Microbiol. Rev. 2004, 28, 519-542. [CrossRef]

46. Heuer, H.; Szczepanowski, R.; Schneiker, S.; Phler, A.; Top, E.M.; Schlüter, A. The complete sequences of plasmids pB2 and pB3 provide evidence for a recent ancestor of the IncP-1b group without any accessory genes. Microbiology 2004, 150, 3591-3599. [CrossRef]

47. Dang, H.Y.; Ren, J.; Song, L.S.; Sun, S.; An, L.G. Dominant chloramphenicol-resistant bacteria and resistance genes in coastal marine waters of Jiaozhou Bay, China. World J. Microb. Biot. 2008, 24, 209-217. [CrossRef]

48. Then, R.L. Mechanisms of resistance to trimethoprim, the sulfonamides, and trimethoprim-sulfamethoxazole. Rev. Infect. Dis. 1982, 4, 261-269. [CrossRef] [PubMed]

49. Wang, N.; Yang, X.; Jiao, S.; Zhang, J.; Ye, B.; Gao, S. Sulfonamide-resistant bacteria and their resistance genes in soils fertilized with manures from Jiangsu province, Southeastern China. PLoS ONE 2014, 9. [CrossRef]

50. Ma, Y.; Wilson, C.A.; Novak, J.T.; Riffat, R.; Aynur, S.; Murthy, S.; Pruden, A. Effect of various sludge digestion conditions on sulfonamide, macrolide, and tetracycline resistance genes and class I integrons. Environ. Sci. Technol. 2011, 45, 7855-7861. [CrossRef]

51. Munir, M.; Wong, K.; Xagoraraki, I. Release of antibiotic resistant bacteria and genes in the effluent and biosolids of five wastewater utilities in Michigan. Water Res. 2011, 45, 681-693. [CrossRef] [PubMed]

52. Mao, D.; Yu, S.; Rysz, M.; Luo, Y.; Yang, F.; Li, F.; Hou, J.; Mu, Q.; Alvarez, P.J. Prevalence and proliferation of antibiotic resistance genes in two municipal wastewater treatment plants. Water Res. 2015, 85, 458-466. [CrossRef] [PubMed] 